\title{
From causes of aging to death from COVID-19
}

Review

\author{
Mikhail V. Blagosklonny ${ }^{1}$ \\ ${ }^{1}$ Roswell Park Cancer Institute, Buffalo, NY 14263, USA
}

Correspondence to: Mikhail V. Blagosklonny; email: Blagosklonny@oncotarget.com or Blagosklonny@rapalogs.com Keywords: aging, mTOR, rapalogs, senolytics, SARS-CoV-2, COVID-19, coronavirus

Received: April 30, 2020

Accepted: June 8, 2020

Published: June 12, 2020

Copyright: Blagosklonny et al. This is an open-access article distributed under the terms of the Creative Commons Attribution License (CC BY 3.0), which permits unrestricted use, distribution, and reproduction in any medium, provided the original author and source are credited.

\begin{abstract}
COVID-19 is not deadly early in life, but mortality increases exponentially with age, which is the strongest predictor of mortality. Mortality is higher in men than in women, because men age faster, and it is especially high in patients with age-related diseases, such as diabetes and hypertension, because these diseases are manifestations of aging and a measure of biological age. At its deepest level, aging (a program-like continuation of developmental growth) is driven by inappropriately high cellular functioning. The hyperfunction theory of quasi-programmed aging explains why COVID-19 vulnerability (lethality) is an age-dependent syndrome, linking it to other age-related diseases. It also explains inflammaging and immunosenescence, hyperinflammation, hyperthrombosis, and cytokine storms, all of which are associated with COVID-19 vulnerability. Anti-aging interventions, such as rapamycin, may slow aging and age-related diseases, potentially decreasing COVID-19 vulnerability.
\end{abstract}

\section{COVID-19 vulnerability: age, diseases, gender}

COVID-19 is caused by coronavirus SARS-CoV-2. Most cases of COVID-19 are asymptomatic, but some are severe and lethal. Mortality is the simplest marker of COVID-19 vulnerability. COVID-19 vulnerability can be defined as a chance of death from COVID-19, once infected.

Age:

In all studies conducted in all countries, the mortality rate from COVID-19 increases exponentially with age [1-11]. Exact mortality rates varied in hundreds of studies because they depend on testing and therapeutic interventions. But the rule is clear: the mortality rate is increasing exponentially with age.

Age-related diseases:

Mortality is especially high in patients with pre-existing conditions $[6,9,10,12-23]$.

In Italy, 99\% of patients, who died, had at least one illness. https://www.bloomberg.com/news/articles/2020-0318/99-of-those-who-died-from-virus-had-other-illnessitaly-says.

In other words, infected people without pre-existing diseases do not die. This may seem paradoxical because we just discussed that age is sufficient to increase mortality exponentially. This is because pre-existing conditions are manifestations of biological age, whereas aging and diseases are two sides of the same coin [2426]. These conditions are typical age-related diseases: hypertension, diabetes, obesity, ischemic heart disease (IHD) and chronic obstructive pulmonary disease (COPD) and other diseases [9, 12-23].

Of course, not all (only some) patients with age-related diseases die from COVID-19. In other words, agerelated diseases are necessary but not sufficient for mortality from COVID-19.

Age and pre-existing (age-related) diseases are interdependent. A number and severity of diseases correlate with age. An average 60 year old person has 
more age-related diseases than an average 50 your old person. Yet, a particular 60 year old person may have no age-related diseases, whereas a particular 50 year old person may have multiple diseases including hypertension, diabetes, obesity and cancer. In this case, it is a chronologically younger person who is biologically older. And it is the biological age that determines the likelihood of death from COVID-19.

\section{Male Gender:}

At the same age, the mortality rate is twice higher in men than in women $[9,27,28]$, in part, because men age faster than women and, at any chronological age, men are biologically older than women [29].

So, three rules can be combined in one: COVID-19 vulnerability is determined by biological age. Biological age combines chronological age, age-related diseases and gender. A combination of all age-related diseases (and pre-diseases) is a biomarker of biological age. Figuratively, SARS-Cov-2 can "measure" biological age, which is thus the best predictor of mortality from both COVID-19 and other diseases.

\section{Mortality from aging compared with COVID-19 mortality}

Aging can be measured as an increase in the probability of death with age. Mortality increases exponentially, starting from age 8-9. Men have a higher "normal" agerelated death rate than women because men age faster than women [29].

COVID-19 mortality rate parallels the "expected" aging-related death rate (Supplementary Figure 1) and see second graph in:

https://medium.com/wintoncentre/how-much-normalrisk-does-covid-represent-4539118e1196.

Chances to die from COVID-19 are proportional to chances to die from aging itself at any age. The only discrepancy between natural and COVID-19 mortality is observed below the age of 8 years old. Whereas natural death rate is relatively high, COVID-19 mortality is low (no mortality [11]). This discrepancy will be discussed later. But first how do animals, including humans, die from aging?

\section{Age-related diseases}

Humans and other animals (including the worm [30] and the fly [31]) do not die from aging itself but from agerelated diseases such as ischemic heart disease (IHD), hypertension, diabetes, cancer, Alzheimer's and Parkinson's diseases, age-related macular degeneration, osteoporosis and sarcopenia (As we will discuss, even seemingly non-deadly diseases such as osteoporosis can lead to deadly complications). The incidence of these diseases increases exponentially with age. Some diseases such as obesity, hypertension and diabetes develop earlier in the course of aging. Other diseases, such as Alzheimer's disease and macular degeneration, are usually diagnosed later [32, 33]. Age-related diseases may also occur in younger people with genetic predisposition and environmental exposure hazards. But even without these factors, diseases develop because they are quasi-programmed (see "Quasi-programmed aging section"). These diseases are not diseases of civilization, as it may seem. Humans simply now live long enough to develop them. Of course, "hazards of civilization" can accelerate them at a younger age.

Aging and its diseases cannot be separated. Healthy aging, or aging without diseases, is merely a slow aging, when biological age is less than chronological age. During a period of seemingly healthy aging, pre-pre-diseases and pre-diseases are progressing until they eventually reach clinical manifestations. Thus, healthy aging progress to unhealthy and pre-diseases become diseases [34].

Age-related diseases and COVID-19 vulnerability are highly intertwined. Patients, who die from COVID-19, otherwise would die from age-related diseases such as heart disease, cancer, diabetes, hypertension, just a year later. COVID-19 approximately doubles a patient's aging-dependent risk of dying during one year. For example, (numbers are very approximate), a sixty year old woman has $1 \%$ chance to die from aging before her 61 st birthday. At that age, if infected, the death rate from COVID-19 is around $1 \%$ for females. If infected, a patient has approximately doubled chances to die compared with usual age-related mortality during one year. As David Spiegelhalter put it: "getting COVID-19 is like packing a year's worth of risk into a week or two". https://medium.com/wintoncentre/how-much-normalrisk-does-covid-represent-4539118e1196.

Children and young adults have a very low risk of death from aging-related diseases, so that risk remains extremely low even when doubled.

Although natural mortality is relatively high in the youngest age group, especially in infants, they do not die from age-related diseases of course. Instead, infants are vulnerable to bacterial infections and candida infections due to underdeveloped immune system [35]. Low COVID-19 mortality in the pediatric age group [11] is consistent with the notion that COVID-19 vulnerability is not due to a "weak" immune system. In contrast, as we will discuss in the next section, it is hyper-functional immune response that leads to death from COVID-19 in the elderly by causing cytokine storm. 


\section{Cytokine storm as a hyperfunction}

Severe COVID-19 is characterized by hyperinflammation, cytokine storm, acute respiratory distress syndrome (ARDS), damage to the lung, heart and kidneys [36-39].

In response to viral replication, hyperfunctional monocytes and macrophages infiltrate the lung, causing hyper-inflammation and hyper-secretion of cytokines such as interleukin (IL)-6, IL-2, IL-7, IL$1 \mathrm{ra}$, interferon- $\gamma$ inducible protein (IP)-10, tumor necrosis factor (TNF)- $\alpha$, ferritin, monocyte chemoattractant protein (MCP)-1, macrophage inflammatory protein (MIP) 1- $\alpha$, granulocyte-colony stimulating factor (G-CSF), C-reactive protein (CRP) and procalcitonin. [22, 36-42].

This leads to leukocyte recruitment, vascular permeability, edema and further pulmonary damage in vicious cycle [37, 38, 41, 43, 44]. Hyper-inflammation becomes systemic, in turn causing hyper-coagulation and thrombosis, disseminated intravascular coagulation [45]. This causes injury of distant organs such as the kidneys. Pre-existing organ damage (late stages of agerelated diseases) exacerbates organ damage caused by cytokine storm [42, 43, 46]. In addition, cellular hyperfunctions and systemic hyper-inflammation may lead to cellular exhaustion, such as exhaustion of lymphocytes (lymphopenia) [47-49]. Hypercoagulation is associated with hyperactive fibrinolysis and increased D-dimer blood levels [23]. Cytokine storm is a systemic hyperfunctional response (Figure 1).
Of course, age-related hyperfunctional response, such as cytokine storm, is not caused by lifelong accumulation of molecular damage. Aging is not caused by molecular damage after all. Instead it's a continuation of developmental/growth programs that lead to hyperfunctions and in turn eventually to dysfunctions.

\section{Hyperfunction theory of quasi-programmed aging}

"Quasi" means "resembling" or "seemingly, but not really." Quasi-program of aging is not a program but a continuation of developmental programs that were not switched off upon their completion [24, 50]. They purposelessly unfold, leading to age-related diseases, secondary organ failure and death. Quasi-programmed (program-like) aging is associated with higher than optimal cellular and systemic functions, which eventually, via cellular exhaustion and organ damage, lead to functional decline (Figure 2). For example, starting from birth, blood pressure increases and continues to increase after organismal growth is completed. Therefore, hypertension is the most prevalent age-related disease. In turn, hypertension can cause organ damage: stroke, infarction and renal failure. Similarly, obesity develops in post-development as a continuation of growth (yet, it can be prevented by low caloric diets, illustrating that quasi-program of aging can be decelerated).

Hyperfunction is an excessive normal cellular function: contraction by smooth muscle cells (SMC), adhesion and aggregation by blood platelets, insulin secretion by

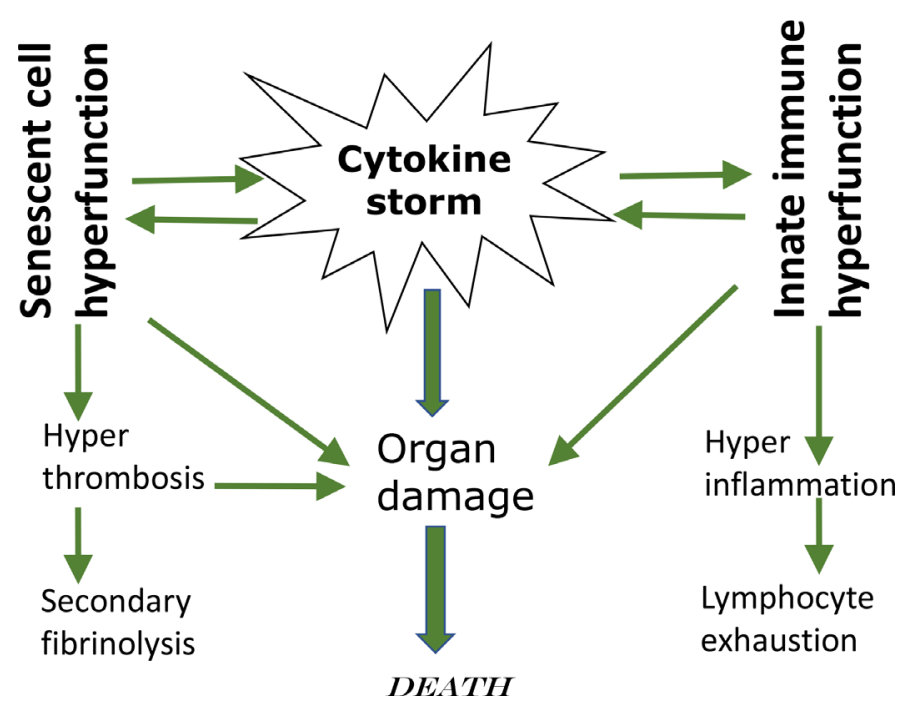

Figure 1. Cytokine storm as a systemic hyperfunction. 
beta-cells, lipid accumulation by adipocytes, secretion by stromal and immune cells, oxidative burst by leukocytes, just to name a few. When higher than optimal, they cause vasoconstriction and hypertension, thrombosis, hyperinsulinemia, hypertrophy, hyperplasia, obesity, hyper-secretory phenotype or Senescence-associated secretory phenotype (SASP), hyper-inflammation and so on.

Hyper-function is not necessarily an absolutely increased function. It may be also insufficiently decreased function (relative hyperfunction). Levels of IGF-1 and growth hormone decrease during lifespan. Despite this decrease, IGF-1 levels are still higher than optimal (relative hyper-function) because further genetic decrease in
IGF-1 levels (by genetic means) extends health span and lifespan in mammals [51-53].

Cellular hyperfunctions may eventually switch to cellular exhaustion and loss of functions at late stages. During the course of type II diabetes, mTOR overactivation and hyperinsulinemia eventually lead to beta-cell exhaustion and insulin insufficiency, from prediabetes to diabetes $[54,55]$. As another example, after puberty, hyperstimulation of the ovary eventually leads to oocyte exhaustion and menopause (see Figure 3 in ref. [29]). Depletion of naïve lymphocytes is another example, as reviewed here later. Age-related alterations are mostly noticed when they switch to functional decline, which is a late event.

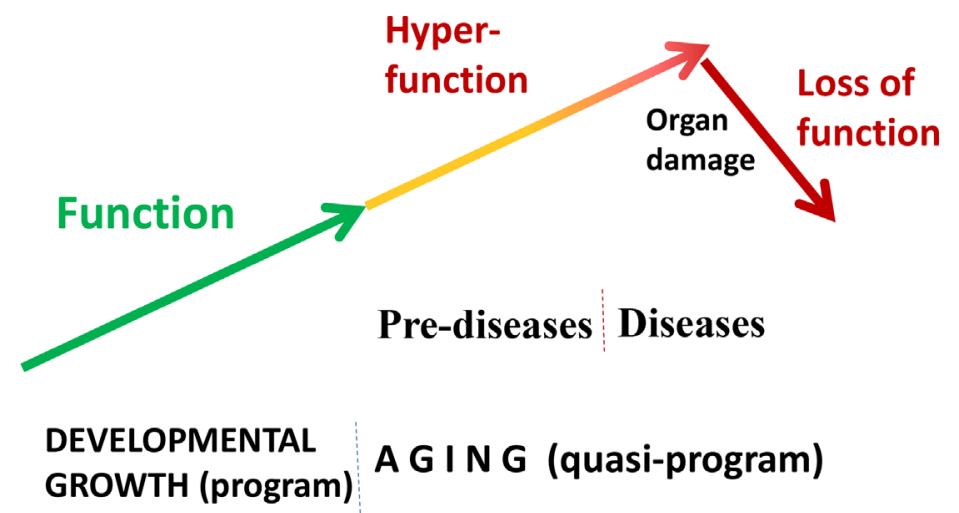

Figure 2. Quasi-programmed hyperfunctional aging. Aging is a continuation of developmental programs that were not switched off upon their completion. An increase in cellular and systemic functions (manifested as pre-diseases and then as diseases) leads to eventual organ damage and secondary loss of function.

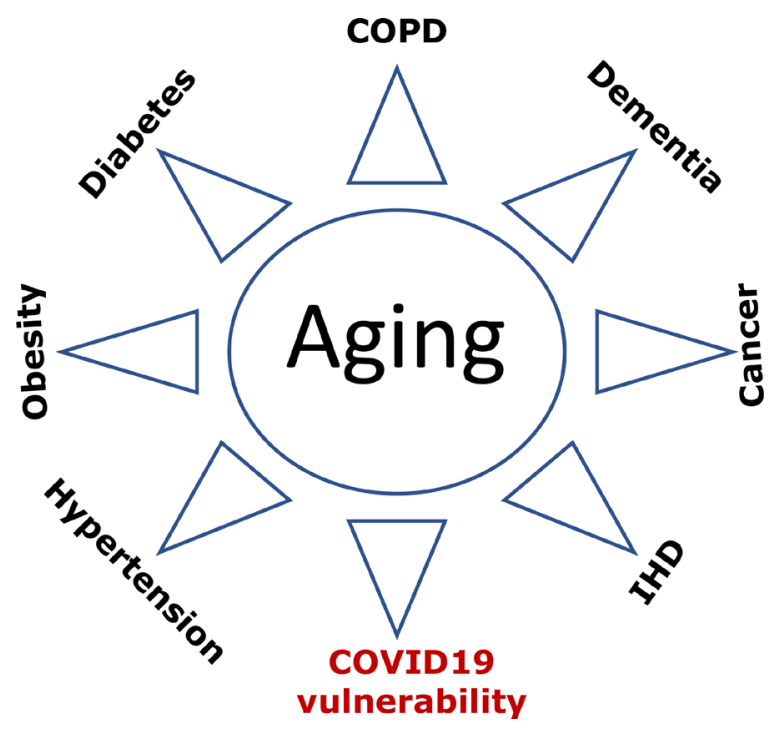

Figure 3. COVID-19 vulnerability as an age-related disease. Age-related diseases, including COVID-19 vulnerability, are manifestations of aging. Abbreviations: Ischemic heart disease (IHD); Chronic obstructive pulmonary disease (COPD). 
In some cases, functional decline can be primary and programmed. For example, thymus involution (replacement of T cells by adipocytes) starts early in life, accelerates at puberty and continues later. Still loss of thymocytes and their niches may be in part due to adipocyte hyperplasia and hypertrophy [56]. In fact, obesity accelerates involution, whereas calorie restriction decelerates it $[57,58]$. Furthermore, the oblation of sex hormones decelerates or even reverses thymus involution [59]. Thus, involution is triggered by adipocyte hyperplasia and increased production of sex hormones during puberty [56].

Quasi-programmed aging is not driven by molecular damage. It is driven by nutrient/hormone/cytokinesensing and growth-promoting signaling pathways such as Target of Rapamycin (TOR; mTOR), which are involved in developmental growth and later cause hyperfunctional aging and its diseases [24, 26].

\section{Covid-19 vulnerability as an age-related syndrome}

What is the cause-effect relationship between age-related diseases and COVID-19 lethality? Do patients die from age-related diseases, complicated by COVID-19? Or, in contrast, do these various diseases make COVID-19 infection lethal? Both scenarios take place to some extent. However, the relationship is mostly indirect. Both age-related diseases and COVID-vulnerability result from the same underlying cause (Figure 3). This is why they are highly correlated. The cause is aging itself. Aging is manifested by a sum of deadly - and not so deadly - diseases and conditions ranging from cancer to grey hair. Although not all diseases seem to be deadly, they can cause complications such as stroke, ventricular fibrillation, renal failure, lung edema. Even sarcopenia and osteoporosis lead to falls and broken bones culminating in a deadly sequence of events. Cosmetic manifestations such as aging spots and wrinkles, while not deadly by themselves, can be manifestations of other diseases. For example, baldness correlates with prostate enlargement [60], and the later can lead to urinary obstruction and renal failure.

Diseases occur together. For example, chronic obstructive pulmonary disease (COPD) is associated with diabetes, cardiovascular disease and hypertension [61]. If a person has one disease (e.g., diabetes), this patient has higher chances of having other diseases (e.g., hypertension, IHD, cancer) or conditions, including COVID-19 vulnerability, which is revealed only during infection but can be predicted by pre-existing diseases.

Aging is initially driven by an increase in cellular and systemic functions (hyperfunction), leading to age- related conditions. For example, hypertension is a systemic hyperfunction due to hyperfunction of multiple cell types such as arterial smooth muscle cells (aSMC). Similarly, COVID-19-vulnerability is associated with hyperfunction of inflammatory cells that, in response to COVID-19 infection, causes cytokine storm, hypercoagulation and damage of the lung and distant organs.

The COVID-19 vulnerability syndrome is an agingrelated disease, strictly dependent on biological age, associated with other age-related diseases, and exemplified by hyper-functional response to infection.

\section{Inflamm-aging and immunosenescence}

With hundreds of cell types acting in concert, the immune system is so complex that we cannot discuss age-related alterations without oversimplification. The most noticeable alteration is that memory $\mathrm{T}$ and $\mathrm{B}$ cells replace naive $T$ and $B$ cells [62]. (This seems natural since life-long exposure to pathogens replaces naïve cells by memory cells). Replacement of naïve immune cells decreases adaptive responses to novel antigens such as SARS-CoV-2. In contrast, immune protection by memory $\mathrm{T}$ cells from viral re-infection with known pathogens is usually increased with age [62].

Immune responses are roughly divided into (a) innate responses, carried mostly by neutrophils, macrophages and NK cells, which react to pathogen rapidly and nonspecifically, and (b) adaptive responses, carried by $\mathrm{T}$ and B lymphocytes, which are delayed, slower and specific (e.g., antigen-specific clonal expansion of $\mathrm{T}$ and $\mathrm{B}$ lymphocytes and antibody production by $\mathrm{B}$ lymphocytes) [63-65]. In the elderly, immune responses to SARS-CoV-1/2 are "stuck in innate immunity," with insufficient progression to adaptive immunity [37]. However, decline in adaptive response, such as antibody production, plays little role in COVID-19 mortality. It is hyper-functional innate immunity, hyper-inflammation, cytokine storm and hyper-coagulation that lead to organ failure and death. In agreement, hyper inflammatory response rather than high virus numbers leads to death of SARS-CoV-infected old nonhuman primates [66].

Aging is associated with diseases of immune hyperfunction such as autoimmune disorders with paradoxical increase in certain signaling pathways and cytokine levels [67-69].

In the elderly, innate immune cells are in a state of sustained activation, producing pro-inflammatory cytokines [67, 70-72]. Increased pro-inflammatory activity by the innate immune system, especially by monocytes/ macrophages, is a state of alertness and hyper-reactivity on the cost of potential age-related inflammatory diseases 
[67, 70-72]. Whereas some functions are decreased, others are increased. According to the inflamm-aging concept, innate immune system overtakes adaptive immune system in aging. Cause-effect relationships are bi-directional: immunosenescence (namely, a decrease in adaptive response) is a cause and consequence of inflamm-aging [67, 70-72].

We can consider inflamm-aging as an example of hyper-function. While some functions are decreased, others are increased. Hyper-function is damaging. (In analogy, increased electric power, without an adaptor, would damage a laptop). Damaging hyper-functions can lead to loss of function and cellular exhaustion. And vice versa, loss of function may cause compensatory hyper-functions of another components.

\section{Cellular senescence as a continuation of growth}

Cellular senescence is a continuation of cellular growth, when actual growth is completed [73, 74]. In proliferating cells, cellular mass growth is balanced by cell division. Cells grow in size and then divide. When the cell cycle is blocked (e.g., p21 and p16), then growth-promoting pathways such as mTOR and MAPK drive conversion to senescence (geroconversion) [24, 74, 75]. During geroconversion, cells become hypertrophic and "fat". Cellular functions increase: hyper-secretion and lysosomal hyper-function are manifested by SASP and beta-Gal staining. Hyper-activated growthpromoting pathways cause compensatory resistance to growth factors/insulin, permanent loss of re-proliferative potential [74]. Rapamycin, everolimus, pan-mTOR and MAPK inhibitors slows down geroconversion, maintaining reversible quiescence instead of senescence $[73,76-88]$.

Geroconversion is a continuation of cellular growth $[73,74]$. Similarly, aging is a continuation of developmental growth (see Figure 1 in ref. [89]). When the developmental program is completed, it becomes a quasi-program of aging. As discussed in detail, chronically activated nutrient-sensing and growth-promoting pathways drive age-related diseases, culminating in organismal death $[24,26]$.

Age-related diseases are quasi-programmed. Aging is a common cause of age-related diseases, a sum of all agerelated diseases. They are diseases of hyper-function, secondary hypo-function and compensation reactions [25]; they are deadly manifestations of aging.

From activation of cellular functions to systemic hyperfunctions, from diseases to organ damage and death, hyperfunction theory of quasi-programmed aging describes the sequence of events [26]. And as discussed in 2006, suppression of aging by gero-suppressants, such as rapamycin, will prevent and treat all age-related diseases [24]. This point of view is becoming widely accepted and, in recent literature, quasi-programmed model of diseases (2006) is called "geroscience hypothesis" $[2,90]$.

\section{Figuratively, rapamycin rejuvenates immunity [91]}

If aging were functional decline due to accumulation of molecular damage, then it would be near to impossible to restore functions and rejuvenate the immune system. In contrast, if functional decline is secondary to hyperfunctions (see Figure 2 in ref. [89]), these hyperfunctions can be suppressed pharmacologically to restore lost functions. Typical drugs are inhibitors of their targets, rather than activators, so they decrease functions of their targets. By decreasing hyper-functions, which otherwise lead to secondary loss of functions, rapamycin may restore "lost" functions (Figure 4).

Rapamycin improves vaccination against viruses such as influenza in old mice, monkeys and humans [92100]. Importantly, rapamycin increases pathogenspecific but not graft-reactive CD8+ $\mathrm{T}$ cell responses $[95,101]$. Therefore, rapamycin and everolimus can both be used to prevent donor organ rejection and improve adaptive immunity against new pathogens [96].

Differentiation is an increase of tissue-specific cellular functions. Terminally differentiated B, T, and NK cells can rapidly react to already known pathogens [102]. Decrease in naïve $\mathrm{T}$ and $\mathrm{B}$ lymphocytes (and thus diminished response to novel antigens) results in part from cellular hyper-differentiation in the immune system [64, 103]. Hyper-functional differentiation can be counteracted by rapamycin [98].

As another example, age-related exhaustion of stem cells is partially due to loss of quiescence caused by growth over-stimulation [92, 104-106]. In general, senescent cells characterized by hyper-proliferative drive coupled with cell cycle arrest [77]. In young mice, mTOR hyperactivation causes senescence of hematopoietic stem cells (HSC) and decreases lymphopoiesis [92]. In old mice, rapamycin rejuvenates hematopoiesis, and improves vaccination against influenza virus [92].

Third, production of lymphoid cells may be decreased because of disruption of hypoxic niches due to adipocytes hyperplasia [56, 107]. Hypoxic niches can preserve HSC [108, 109] probably because hypoxia inhibits mTOR and cellular senescence [110]. In agreement, rapamycin preserves HSCs [92, 98, 111, 112] reduces the proportion of memory cells and maintains a pool of naïve $\mathrm{T}$ cells $[92,98]$. 
Fourth, growth factor (GF)- and insulin-resistance is loss of function because cells cannot respond to $\mathrm{GF} /$ insulin. But it may be caused by over-activated mTOR, which via S6K/IRS feedback loop blocks insulin and GF signaling. Rapamycin abrogates the loop restoring signaling [113-118].

\section{Anti-aging medicine}

A high prevalence of age-related diseases, often called "diseases of civilization," is a success story of modern medicine. In the past, most people did not live long enough to develop age-related diseases and those who developed them died soon after. Due to medical advances, people survive to 85 on average, despite suffering from age-related diseases. Standard medicine preferentially extends life span, without necessarily affecting health span (see Figure 3 in ref. [119]). For example, defibrillation and coronary stenting can save life but not cure heart disease. It is anti-aging interventions that extend health span, delaying diseases, thus extending lifespan. Aging is a common cause of all age-related diseases. By suppressing aging, anti-aging interventions may delay all age-related diseases [119].

As a well-known example, low calorie diets such as calorie restriction, intermittent fasting, and low carbohydrate diets extend both health and lifespan. Figuratively, low calorie diets prolong life by improving health. Nutrients and obesity activate growth-promoting pathways (e.g., mTOR), thus accelerating development of quasi-programmed (age-related) diseases. Obesity is associated with all age-related diseases from cancer to Alzheimer's and from diabetes to sarcopenia. COVID19 vulnerability is also associated with obesity [9, 19, 20, 22]. According to hyperfunction theory, obesity accelerates aging and all age-related conditions including COVID-19 vulnerability.

Diabetes is one of main risk factors of death in COVID$19[5,6,12,13,15,21]$. Can type 2 diabetes, an agerelated disease, be reversed? In remarkable studies, it was shown that a brief course (6-8 weeks) of very low calorie diets (VLCDs) can reverse type II diabetes. In one study, VLCD reversed diabetes in $46 \%$ of patients with up to a 6-year history of diabetes [120]. VLCD is most effective for its prevention and at early stages of diabetes [121]. This anti-aging modality is so simple that remission can be achieved at home by healthmotivated individuals [122]. Simultaneously, it treats other age-related diseases such hypertension [123]. Obesity is associated with other diseases of hyperfunction from diabetes and sarcopenia to cancer and Alzheimer's' disease. Since age-related diseases are predictors of COVID-19 mortality, VLCD in theory may decrease COVID-19 vulnerability.

\section{Rapamycin and everolimus as anti-aging drugs}

In the soil of Easter Island, a complex bacteria produces anti-fungal antibiotic rapamycin to suppress yeast growth but, as a by-product, it also suppresses yeast aging (quasi-programed aging is a continuation of growth). Approved for human use in 1999, Rapamycin

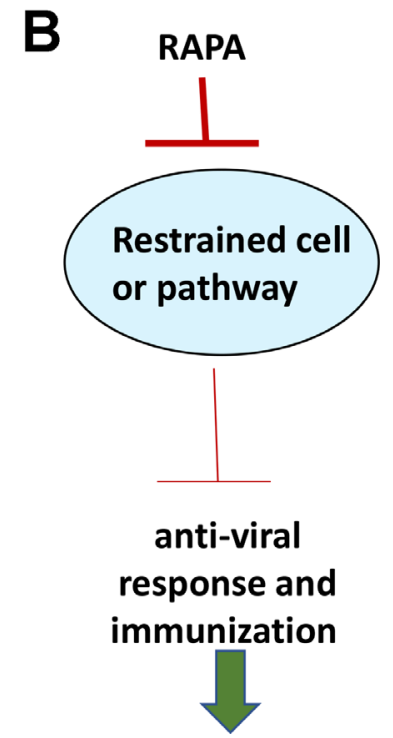

Figure 4. Rejuvenating immunity by inhibiting hyperfunction. (A) Specific hyper-functional cells (or signaling pathways) can inhibit some other cell types (or pathways) that are needed for proper anti-viral response and immunization. (B) By inhibiting hyper-functional cells or pathways, rapamycin can reactivate "loss-of-function" otherwise suppressed by hyper-functional cells or pathways. 
(Sirolimus) and its close analog Everolimus are widely used in several diseases including cancer and organ transplantation. Hundreds of clinical trials (and twenty years of clinical practice) have ensured their safety and good tolerability especially in healthy older adults [119].

Currently, several anti-aging clinics prescribe rapamycin out of label to prevent age-related diseases and slow aging. Hundreds of recent reviews discussed rapamycin and everolimus in detail, so I will just emphasize a few points:

1. Crucial prediction of hyper-function theory of quasi-programmed aging in 2006 was that rapamycin will slow aging, extend healthspan and lifespan and decrease all age-related [124]. It has been confirmed: it extends lifespan in animals from worm to mammals. In some strains of short-lived mutant mice, it extends life span two fold [98, 125].

2. Rapamycin slows geroconversion to cellular senescence in cell culture [74].

3. mTOR is a potential therapeutic target in chronic obstructive pulmonary disease COPD [126], [127]. Rapamycin (sirolimus) is already approved and successfully used in lymphangioleiomyomatosis (LAM), a progressive, cystic lung disease, associated with inappropriate activation of mTOR [128]. Longterm daily use of rapamycin improves lung function without causing serious side effects (and of course no even minor side effects in the lung, given that rapamycin improves lung function) [128].

4. Despite widespread misunderstanding, rapamycin and everolimus do not cause diabetes. In contrast, they prevent diabetic complications in animals with diabetes (see for references [129]). In rodents, in some conditions they may cause symptoms of starvation pseudo-diabetes similar to prolong fasting and ketogenic diet [129]. Although, the Johnson study found a slight but significant correlation between Medicare billing for insulin and the use of rapamycin in renal transplant patients, this correlation was mechanistically explained by interaction of rapamycin with two other drugs used in the same patients $[130,131]$. In cancer patients, everolimus may cause reversible hyperglycemia as a mild, infrequent and reversible side effect after several weeks of daily high doses of everolimus and rapamycin [132]. Mechanistically, everolimus decrease insulin production, not causing insulin resistance [132]. If anything, everolimus and rapamycin can be considered to treat complications of type II diabetes and prevent hyperinsulinemia and obesity ([129] and references within). What actually contributes to type 2 diabetes is excess of nutrients (and especially carbohydrates), which activate mTOR and cause hyperinsulinemia and insulin resistance.

\section{Potential applications of rapamycin/everolimus to COVID-19}

As soon as COVID-19 epidemic started, it become clear that COVID-19 vulnerability is an aging-dependent condition and the use of rapamycin (Sirolimus) was immediately suggested by independent researchers [1, 3, 133-137]. These proposals were based on a mixture of several rationales, which need to be clearly distinguished. In theory, there are at least three independent applications of rapamycin and everolimus for COVID-19. Currently, they all are still hypothetical.

1. Anti-aging effect (Figure 5). By decreasing biological age and preventing age-related diseases, a long-term rapamycin therapy may in theory decrease COVID-19 mortality rate in the elderly. Anti-aging application is especially important because it is beneficial regardless of COVID-19. After all, mortality rate from aging and its diseases is $100 \%$, causing more than 2 million deaths in the USA annually. Continuous use of rapamycin is expected to improve health, decrease age-related diseases and extend healthy lifespan, rendering individuals less vulnerable, when infected with the virus.

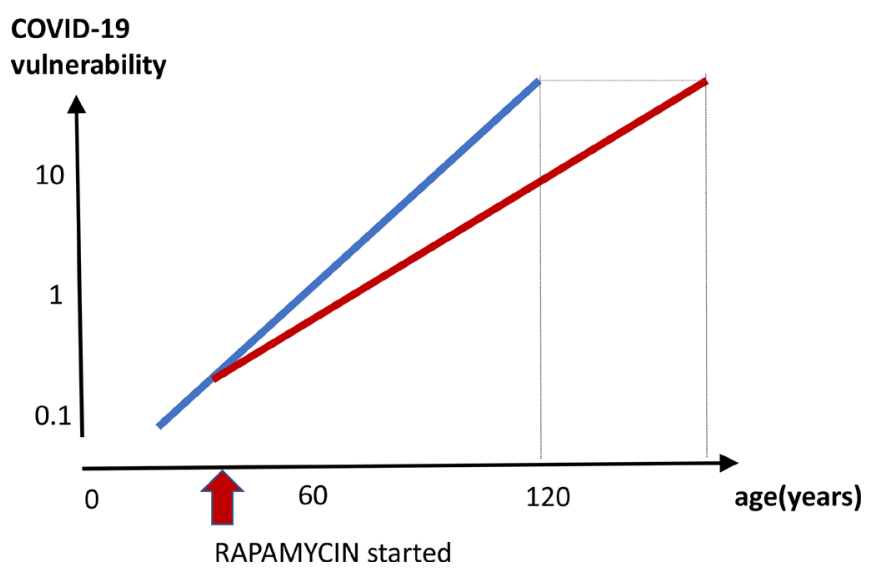

Figure 5. Prevention of COVID-19 vulnerability by staying young. Hypothetical graph in the absence of COVID-19. COVID19 vulnerability (log scale) increases exponentially with age (blue line). The line ends at age 120, a maximum recorded age for humans. In theory, a continuous rapamycin treatment would slow down an increase of the vulnerability with age (red line). The increase is still logarithmic but at a different slope, because rapamycin slows the aging process. The maximum lifespan, in the absence of COVID-19, is extended because the $100 \%$ natural death threshold is achieved later. 
2. Rejuvenating immunity. As we discussed in section "Figuratively, rapamycin rejuvenates immunity" [91], mTOR inhibitors can improve immunity to viral infections, improve immunization and vaccination to some viruses such as flu [92-100, $111,112,138]$. In addition, viruses such as flu [139] and coronavirus (MERS-CoV) [140] depend on mTOR activity for replication. Currently, however, there are no data regarding COVID-19. Although aimed to evaluate safety, Phase 1 clinical trial "Sirolimus in COVID-19 Phase 1 (SirCO-1)" may reveal anti-viral effects too

https://clinicaltrials.gov/ct2/show/NCT04371640.

3. Potential suppression of cytokine storm and hyperinflammation (Figure 1). As we discussed in the section "Cytokine storm is a hyperfunction", cytokine storm and hyper-inflammation is a main cause of death in COVID-19 pneumonia [36-40, $42,45,135$, 141-143] Rapamycin, an antiinflammatory agent, inhibits hyper-functions, cellular senescence and decrease secretion of cytokines ([74, 81, 144]. Rapamycin inhibits the Jak2/Stat4 signaling pathway [145] and reduces IF$\gamma$ and TNF- $\alpha$ levels [112]. Rapamycin (Sirolimus) treatment improves outcomes in patients with severe H1N1 pneumonia and acute respiratory failure and was associated with improvement in virus clearance, and shortened ventilator days [146]. Clinical trial "Sirolimus Treatment in Hospitalized Patients With COVID-19 Pneumonia (SCOPE)" has been started https://clinicaltrials.gov/ct2/show/NCT04341675.

\section{Disclaimer}

This review is intended for a professional audience, to stimulate new ideas and to aid the global efforts to develop effective treatments for COVID-19 disease. This article does not represent medical advice or recommendations to patients. The media should exercise caution and seek expert medical advice for interpretation, when referring to this article.

\section{CONFLICTS OF INTEREST}

The author declares no conflicts of interest.

\section{REFERENCES}

1. Zhavoronkov A. Geroprotective and senoremediative strategies to reduce the comorbidity, infection rates, severity, and lethality in gerophilic and gerolavic infections. Aging (Albany NY). 2020; 12:6492-510. https://doi.org/10.18632/aging.102988 PMID:32229705
2. Promislow DE. A geroscience perspective on COVID-19 mortality. J Gerontol A Biol Sci Med Sci. 2020. [Epub ahead of print]. https://doi.org/10.1093/gerona/glaa094 PMID:32300796

3. Sargiacomo C, Sotgia F, Lisanti MP. COVID-19 and chronological aging: senolytics and other anti-aging drugs for the treatment or prevention of corona virus infection? Aging (Albany NY). 2020; 12:6511-17. https://doi.org/10.18632/aging.103001 PMID: $\underline{32229706}$

4. Leung C. Risk factors for predicting mortality in elderly patients with COVID-19: a review of clinical data in China. Mech Ageing Dev. 2020; 188:111255. https://doi.org/10.1016/j.mad.2020.111255 PMID: $\underline{32353398}$

5. Zhou F, Yu T, Du R, Fan G, Liu Y, Liu Z, Xiang J, Wang Y, Song B, Gu X, Guan L, Wei Y, Li H, et al. Clinical course and risk factors for mortality of adult inpatients with COVID-19 in wuhan, China: a retrospective cohort study. Lancet. 2020; 395:1054-62. https://doi.org/10.1016/S0140-6736(20)30566-3 PMID:32171076

6. Wu C, Chen X, Cai Y, Xia J, Zhou X, Xu S, Huang H, Zhang L, Zhou X, Du C, Zhang Y, Song J, Wang S, et al. Risk factors associated with acute respiratory distress syndrome and death in patients with coronavirus disease 2019 pneumonia in wuhan, China. JAMA Intern Med. 2020. [Epub ahead of print]. https://doi.org/10.1001/jamainternmed.2020.0994 PMID: $\underline{32167524}$

7. Lauc G, Sinclair D. Biomarkers of biological age as predictors of COVID-19 disease severity. Aging (Albany NY). 2020; 12:6490-91.

https://doi.org/10.18632/aging.103052

PMID: 32268300

8. Du RH, Liang LR, Yang CQ, Wang W, Cao TZ, Li M, Guo GY, Du J, Zheng CL, Zhu Q, Hu M, Li XY, Peng P, Shi HZ. Predictors of mortality for patients with COVID-19 pneumonia caused by SARS-CoV-2: a prospective cohort study. Eur Respir J. 2020; 55:2000524. https://doi.org/10.1183/13993003.00524-2020 PMID:32269088

9. Palaiodimos L, Kokkinidis DG, Li W, Karamanis D, Ognibene J, Arora S, Southern WN, Mantzoros CS. Severe obesity, increasing age and male sex are independently associated with worse in-hospital outcomes, and higher in-hospital mortality, in a cohort of patients with COVID-19 in the bronx, new york. Metabolism. 2020; 108:154262. https://doi.org/10.1016/i.metabol.2020.154262 PMID: $\underline{32422233}$ 
10. Banerjee A, Pasea L, Harris S, Gonzalez-Izquierdo A, Torralbo A, Shallcross L, Noursadeghi M, Pillay D, Sebire N, Holmes C, Pagel C, Wong WK, Langenberg C, et al. Estimating excess 1-year mortality associated with the COVID-19 pandemic according to underlying conditions and age: a population-based cohort study. Lancet. 2020; 395:1715-25.

https://doi.org/10.1016/S0140-6736(20)30854-0

PMID:32405103

11. Lu Q, Shi Y. Coronavirus disease (COVID-19) and neonate: what neonatologist need to know. J Med Virol. 2020; 10:1002.

https://doi.org/10.1002/jmv.25740

PMID: $\underline{32115733}$

12. Hussain A, Bhowmik B, do Vale Moreira NC. COVID-19 and diabetes: knowledge in progress. Diabetes Res Clin Pract. 2020; 162:108142.

https://doi.org/10.1016/j.diabres.2020.108142

PMID:32278764

13. Huang I, Lim MA, Pranata R. Diabetes mellitus is associated with increased mortality and severity of disease in COVID-19 pneumonia - a systematic review, meta-analysis, and meta-regression. Diabetes Metab Syndr. 2020; 14:395-403.

https://doi.org/10.1016/i.dsx.2020.04.018

PMID:32334395

14. Mehra MR, Desai SS, Kuy S, Henry TD, Patel AN. Cardiovascular disease, drug therapy, and mortality in covid-19. N Engl J Med. 2020. [Epub ahead of print]. https://doi.org/10.1056/NEJMoa2007621 PMID:32356626

15. Yan $Y$, Yang $Y$, Wang $F$, Ren $H$, Zhang S, Shi X, Yu X, Dong K. Clinical characteristics and outcomes of patients with severe covid-19 with diabetes. BMJ Open Diabetes Res Care. 2020; 8:e001343.

https://doi.org/10.1136/bmjdrc-2020-001343

PMID: $\underline{32345579}$

16. Guzik TJ, Mohiddin SA, Dimarco A, Patel V, Savvatis K, Marelli-Berg FM, Madhur MS, Tomaszewski M, Maffia P, D’Acquisto F, Nicklin SA, Marian AJ, Nosalski R, et al. COVID-19 and the cardiovascular system: implications for risk assessment, diagnosis, and treatment options. Cardiovasc Res. 2020. [Epub ahead of print]. https://doi.org/10.1093/cvr/cvaa106 PMID:32352535

17. Hu J, Zhang $X$, Zhang $X$, Zhao $H$, Lian J, Hao S, Jia H, Yang $M$, Lu $Y$, Xiang $D$, Cai $H$, Zhang $S, G u ~ J$, et al. COVID-19 patients with hypertension have more severity condition, and ACEI/ARB treatment have no infulence on the clinical severity and outcome. J Infect. 2020; S0163-4453:30334-30. https://doi.org/10.1016/i.jinf.2020.05.056 PMID:32474032
18. Zhang J, Wu J, Sun X, Xue H, Shao J, Cai W, Jing Y, Yue $M$, Dong C. Association of hypertension with the severity and fatality of SARS-CoV-2 infection: a metaanalysis. Epidemiol Infect. 2020; 148:e106.

https://doi.org/10.1017/S095026882000117X

PMID:32460927

19. Dietz W, Santos-Burgoa C. Obesity and its implications for COVID-19 mortality. Obesity (Silver Spring). 2020; 28:1005.

https://doi.org/10.1002/oby. 22818 PMID:32237206

20. Zhang F, Xiong Y, Wei Y, Hu Y, Wang F, Li G, Liu K, Du R, Wang $C Y$, Zhu W. Obesity predisposes to the risk of higher mortality in young COVID-19 patients. J Med Virol. 2020. [Epub ahead of print]. https://doi.org/10.1002/imv.26039 PMID: $\underline{32437016}$

21. Wang B, Li R, Lu Z, Huang Y. Does comorbidity increase the risk of patients with COVID-19: evidence from meta-analysis. Aging (Albany NY). 2020; 12:6049-57. https://doi.org/10.18632/aging.103000 PMID:32267833

22. Korakas E, Ikonomidis I, Kousathana F, Balampanis K, Kountouri A, Raptis A, Palaiodimou L, Kokkinos A, Lambadiari V. Obesity and COVID-19: immune and metabolic derangement as a possible link to adverse clinical outcomes. Am J Physiol Endocrinol Metab. 2020. [Epub ahead of print]. https://doi.org/10.1152/ajpendo.00198.2020 PMID:32459524

23. Ji HL, Zhao R, Matalon S, Matthay MA. Elevated plasmin(ogen) as a common risk factor for COVID-19 susceptibility. Physiol Rev. 2020; 100:1065-75.

https://doi.org/10.1152/physrev.00013.2020 PMID:32216698

24. Blagosklonny MV. Aging and immortality: quasiprogrammed senescence and its pharmacologic inhibition. Cell Cycle. 2006; 5:2087-102.

https://doi.org/10.4161/cc.5.18.3288

PMID:17012837

25. Blagosklonny MV. Validation of anti-aging drugs by treating age-related diseases. Aging (Albany NY). 2009; 1:281-88.

https://doi.org/10.18632/aging.100034 PMID:20157517

26. Blagosklonny MV. Prospective treatment of agerelated diseases by slowing down aging. Am J Pathol. 2012; 181:1142-46. https://doi.org/10.1016/i.ajpath.2012.06.024 PMID:22841821

27. Gebhard C, Regitz-Zagrosek V, Neuhauser HK, Morgan $\mathrm{R}$, Klein SL. Impact of sex and gender on COVID-19 
outcomes in europe. Biol Sex Differ. 2020; 11:29. https://doi.org/10.1186/s13293-020-00304-9 PMID:32450906

28. Jin JM, Bai P, He W, Wu F, Liu XF, Han DM, Liu S, Yang JK. Gender differences in patients with COVID-19: focus on severity and mortality. Front Public Health. 2020; 8:152.

https://doi.org/10.3389/fpubh.2020.00152

PMID:32411652

29. Blagosklonny MV. Why men age faster but reproduce longer than women: $\mathrm{mTOR}$ and evolutionary perspectives. Aging (Albany NY). 2010; 2:265-73.

https://doi.org/10.18632/aging.100149

PMID:20519781

30. Wang $H$, Zhang $Z$, Gems D. Monsters in the uterus: teratoma-like tumors in senescent $\mathrm{C}$. Elegans result from a parthenogenetic quasi-program. Aging (Albany NY). 2018; 10:1188-89.

https://doi.org/10.18632/aging.101486

PMID:29923830

31. Xi J, Cai J, Cheng Y, Fu Y, Wei W, Zhang Z, Zhuang Z, Hao Y, Lilly MA, Wei Y. The TORC1 inhibitor Nprl2 protects age-related digestive function in Drosophila. Aging (Albany NY). 2019; 11:9811-28.

https://doi.org/10.18632/aging.102428

PMID:31712450

32. Blagosklonny MV. Answering the ultimate question "what is the proximal cause of aging?". Aging (Albany NY). 2012; 4:861-77. https://doi.org/10.18632/aging.100525 PMID:23425777

33. Corrada MM, Brookmeyer R, Paganini-Hill A, Berlau D, Kawas $\mathrm{CH}$. Dementia incidence continues to increase with age in the oldest old: the 90+ study. Ann Neurol. 2010; 67:114-21.

https://doi.org/10.1002/ana.21915

PMID:20186856

34. Blagosklonny MV. Disease or not, aging is easily treatable. Aging (Albany NY). 2018; 10:3067-78. https://doi.org/10.18632/aging.101647 PMID:30448823

35. Williams EJ, Embleton ND, Bythell M, Ward Platt MP, Berrington JE. The changing profile of infant mortality from bacterial, viral and fungal infection over two decades. Acta Paediatr. 2013; 102:999-1004.

https://doi.org/10.1111/apa.12341

PMID:23826761

36. Akhmerov A, Marbán E. COVID-19 and the heart. Circ Res. 2020; 126:1443-55. https://doi.org/10.1161/CIRCRESAHA.120.317055 PMID:32252591
37. Nikolich-Zugich J, Knox KS, Rios CT, Natt B, Bhattacharya D, Fain MJ. SARS-CoV-2 and COVID-19 in older adults: what we may expect regarding pathogenesis, immune responses, and outcomes. Geroscience. 2020; 42:505-14. https://doi.org/10.1007/s11357-020-00186-0 PMID:32274617

38. Ye $\mathrm{Q}$, Wang $\mathrm{B}, \mathrm{Mao} \mathrm{J}$. The pathogenesis and treatment of the 'Cytokine storm' in COVID-19. J Infect. 2020; 80:607-13.

https://doi.org/10.1016/j.jinf.2020.03.037 PMID:32283152

39. Henderson LA, Canna SW, Schulert GS, Volpi S, Lee PY, Kernan KF, Caricchio R, Mahmud S, Hazen MM, Halyabar O, Hoyt KJ, Han J, Grom AA, et al. On the alert for cytokine storm: immunopathology in COVID-19. Arthritis Rheumatol. 2020; 10:1002. https://doi.org/10.1002/art.41285 PMID:32293098

40. Yao Z, Zheng Z, Wu K, Junhua Z. Immune environment modulation in pneumonia patients caused by coronavirus: SARS-COV, MERS-COV and SARS-CoV-2. Aging (Albany NY). 2020; 12:7639-51. https://doi.org/10.18632/aging.103101 PMID:32364527

41. Yang $Y$, Shen $C$, Li J, Yuan J, Wei J, Huang F, Wang F, Li $\mathrm{G}$, Li Y, Xing L, Peng L, Yang $\mathrm{M}$, Cao $\mathrm{M}$, et al. Plasma IP10 and MCP-3 levels are highly associated with disease severity and predict the progression of COVID-19. J Allergy Clin Immunol. 2020; S0091-6749:30576-75. https://doi.org/10.1016/i.jaci.2020.04.027 PMID:32360286

42. McGonagle D, Sharif K, O'Regan A, Bridgewood C. The role of cytokines including interleukin-6 in COVID-19 induced pneumonia and macrophage activation syndrome-like disease. Autoimmun Rev. 2020; 19:102537. https://doi.org/10.1016/i.autrev.2020.102537 PMID:32251717

43. Vaninov N. In the eye of the COVID-19 cytokine storm. Nat Rev Immunol. 2020; 20:277. https://doi.org/10.1038/s41577-020-0305-6 PMID:32249847

44. Rothan HA, Byrareddy SN. The epidemiology and pathogenesis of coronavirus disease (COVID-19) outbreak. J Autoimmun. 2020; 109:102433. https://doi.org/10.1016/i.jaut.2020.102433 PMID:32113704

45. Dolhnikoff M, Duarte-Neto AN, de Almeida Monteiro RA, da Silva LF, de Oliveira EP, Saldiva PH, Mauad T, Negri EM. Pathological evidence of pulmonary thrombotic phenomena in severe COVID-19. J Thromb Haemost. 2020; 18:1517-19. 
https://doi.org/10.1111/jth.14844 PMID:32294295

46. Siddiqi HK, Mehra MR. COVID-19 illness in native and immunosuppressed states: a clinical-therapeutic staging proposal. J Heart Lung Transplant. 2020; 39:405-07.

https://doi.org/10.1016/i.healun.2020.03.012

PMID: $\underline{32362390}$

47. Fathi N, Rezaei N. Lymphopenia in COVID-19: therapeutic opportunities. Cell Biol Int. 2020. [Epub ahead of print].

https://doi.org/10.1002/cbin.11403

PMID:32458561

48. Cao X. COVID-19: immunopathology and its implications for therapy. Nat Rev Immunol. 2020; 20:269-70.

https://doi.org/10.1038/s41577-020-0308-3

PMID:32273594

49. Tan L, Wang Q, Zhang D, Ding J, Huang Q, Tang YQ, Wang Q, Miao H. Lymphopenia predicts disease severity of COVID-19: a descriptive and predictive study. Signal Transduct Target Ther. 2020; 5:33.

https://doi.org/10.1038/s41392-020-0148-4

PMID:32296069

50. Blagosklonny MV. Aging is not programmed: genetic pseudo-program is a shadow of developmental growth. Cell Cycle. 2013; 12:3736-42.

51. Junnila RK, List EO, Berryman DE, Murrey JW, Kopchick JJ. The GH/IGF-1 axis in ageing and longevity. Nat Rev Endocrinol. 2013; 9:366-76.

https://doi.org/10.1038/nrendo.2013.67

PMID:23591370

52. Bartke A, List EO, Kopchick JJ. The somatotropic axis and aging: benefits of endocrine defects. Growth Horm IGF Res. 2016; 27:41-45.

https://doi.org/10.1016/i.ghir.2016.02.002

PMID:26925766

53. Junnila RK, Duran-Ortiz S, Suer O, Sustarsic EG, Berryman DE, List EO, Kopchick JJ. Disruption of the GH receptor gene in adult mice increases maximal lifespan in females. Endocrinology. 2016; 157:4502-13.

https://doi.org/10.1210/en.2016-1649

PMID:27732088

54. Guillén C, Benito M. mTORC1 overactivation as a key aging factor in the progression to type 2 diabetes mellitus. Front Endocrinol (Lausanne). 2018; 9:621.

https://doi.org/10.3389/fendo.2018.00621

PMID:30386301

55. Yuan T, Rafizadeh S, Gorrepati KD, Lupse B, Oberholzer J, Maedler K, Ardestani A. Reciprocal regulation of mTOR complexes in pancreatic islets from humans with type 2 diabetes. Diabetologia. 2017; 60:668-78. https://doi.org/10.1007/s00125-016-4188-9 PMID:28004151

56. Chinn IK, Blackburn CC, Manley NR, Sempowski GD. Changes in primary lymphoid organs with aging. Semin Immunol. 2012; 24:309-20.

https://doi.org/10.1016/j.smim.2012.04.005 PMID:22559987

57. Yang H, Youm YH, Vandanmagsar B, Rood J, Kumar KG, Butler AA, Dixit VD. Obesity accelerates thymic aging. Blood. 2009; 114:3803-12. https://doi.org/10.1182/blood-2009-03-213595 PMID:19721009

58. Yang $\mathrm{H}$, Youm $\mathrm{YH}$, Dixit VD. Inhibition of thymic adipogenesis by caloric restriction is coupled with reduction in age-related thymic involution. J Immunol. 2009; 183:3040-52.

https://doi.org/10.4049/jimmunol.0900562 PMID:19648267

59. Hince M, Sakkal S, Vlahos K, Dudakov J, Boyd R, Chidgey $A$. The role of sex steroids and gonadectomy in the control of thymic involution. Cell Immunol. 2008; 252:122-38.

https://doi.org/10.1016/i.cellimm.2007.10.007 PMID:18294626

60. Ramsamy K, Subramaniyan R, Patra AK. An observational study of the association between androgenetic alopecia and size of the prostate. Int J Trichology. 2016; 8:62-66. https://doi.org/10.4103/0974-7753.188034 PMID:27601858

61. Mannino DM, Thorn D, Swensen A, Holguin F. Prevalence and outcomes of diabetes, hypertension and cardiovascular disease in COPD. Eur Respir J. 2008; 32:962-69. https://doi.org/10.1183/09031936.00012408 PMID:18579551

62. Davenport B, Eberlein J, Nguyen TT, Victorino F, Jhun K, Abuirqeba $H$, van der Heide $V$, Heeger $P$, Homann D. Aging boosts antiviral $\mathrm{CD} 8+\mathrm{T}$ cell memory through improved engagement of diversified recall response determinants. PLoS Pathog. 2019; 15:e1008144. https://doi.org/10.1371/journal.ppat.1008144 PMID:31697793

63. Netea MG, Joosten LA, Latz E, Mills KH, Natoli G, Stunnenberg HG, O'Neill LA, Xavier RJ. Trained immunity: a program of innate immune memory in health and disease. Science. 2016; 352:aaf1098.

https://doi.org/10.1126/science.aaf1098 PMID:27102489

64. Pereira BI, Akbar AN. Convergence of innate and adaptive immunity during human aging. Front Immunol. 2016; 7:445. 
https://doi.org/10.3389/fimmu.2016.00445 PMID:27867379

65. Nikolich-Žugich J. The twilight of immunity: emerging concepts in aging of the immune system. Nat Immunol. 2018; 19:10-19.

https://doi.org/10.1038/s41590-017-0006-x

PMID:29242543

66. Smits SL, de Lang A, van den Brand JM, Leijten LM, van IJcken WF, Eijkemans MJ, van Amerongen G, Kuiken T, Andeweg AC, Osterhaus AD, Haagmans BL. Exacerbated innate host response to SARS-CoV in aged non-human primates. PLoS Pathog. 2010; 6:e1000756. https://doi.org/10.1371/journal.ppat.1000756 PMID:20140198

67. Fulop T, Dupuis G, Baehl S, Le Page A, Bourgade K, Frost E, Witkowski JM, Pawelec G, Larbi A, Cunnane S. From inflamm-aging to immune-paralysis: a slippery slope during aging for immune-adaptation. Biogerontology. 2016; 17:147-57. https://doi.org/10.1007/s10522-015-9615-7 PMID:26472173

68. Montgomery RR, Shaw AC. Paradoxical changes in innate immunity in aging: recent progress and new directions. J Leukoc Biol. 2015; 98:937-43. https://doi.org/10.1189/jlb.5MR0315-104R PMID:26188078

69. Rostamzadeh D, Yousefi M, Haghshenas MR, Ahmadi M, Dolati S, Babaloo Z. mTOR signaling pathway as a master regulator of memory $\mathrm{CD}^{+}$t-cells, Th17, and NK cells development and their functional properties. J Cell Physiol. 2019; 234:12353-68.

https://doi.org/10.1002/jcp.28042

PMID:30710341

70. Franceschi $C$, Bonafè $M$, Valensin S, Olivieri F, De Luca M, Ottaviani E, De Benedictis G. Inflamm-aging. An evolutionary perspective on immunosenescence. Ann N Y Acad Sci. 2000; 908:244-54. https://doi.org/10.1111/j.1749-6632.2000.tb06651.x PMID:10911963

71. Fulop T, Larbi A, Dupuis G, Le Page A, Frost EH, Cohen AA, Witkowski JM, Franceschi C. Immunosenescence and inflamm-aging as two sides of the same coin: friends or foes? Front Immunol. 2018; 8:1960.

https://doi.org/10.3389/fimmu.2017.01960

PMID:29375577

72. Franceschi C, Campisi J. Chronic inflammation (inflammaging) and its potential contribution to ageassociated diseases. J Gerontol A Biol Sci Med Sci. 2014 (Suppl 1); 69:S4-9. https://doi.org/10.1093/gerona/glu057 PMID:24833586

73. Demidenko ZN, Blagosklonny MV. Growth stimulation leads to cellular senescence when the cell cycle is blocked. Cell Cycle. 2008; 7:3355-61.

https://doi.org/10.4161/cc.7.21.6919 PMID:18948731

74. Blagosklonny MV. Rapamycin, proliferation and geroconversion to senescence. Cell Cycle. 2018; 17:2655-65.

https://doi.org/10.1080/15384101.2018.1554781 PMID:30541374

75. Blagosklonny MV. Cell senescence and hypermitogenic arrest. EMBO Rep. 2003; 4:358-62.

https://doi.org/10.1038/sj.embor.embor806 PMID:12671679

76. Demidenko ZN, Shtutman M, Blagosklonny MV. Pharmacologic inhibition of MEK and PI-3K converges on the mTOR/S6 pathway to decelerate cellular senescence. Cell Cycle. 2009; 8:1896-900.

https://doi.org/10.4161/cc.8.12.8809

PMID:19478560

77. Leontieva OV, Demidenko ZN, Blagosklonny MV. MEK drives cyclin D1 hyperelevation during geroconversion. Cell Death Differ. 2013; 20:1241-49.

https://doi.org/10.1038/cdd.2013.86 PMID:23852369

78. Sousa-Victor P, García-Prat L, Muñoz-Cánoves P. Dual mTORC1/C2 inhibitors: gerosuppressors with potential anti-aging effect. Oncotarget. 2015; 6:23052-54.

https://doi.org/10.18632/oncotarget.5563 PMID:26375366

79. Leontieva OV, Blagosklonny MV. Gerosuppression by pan-mTOR inhibitors. Aging (Albany NY). 2016; 8:3535-51.

https://doi.org/10.18632/aging.101155 PMID:28077803

80. Walters HE, Deneka-Hannemann S, Cox LS. Reversal of phenotypes of cellular senescence by pan-mTOR inhibition. Aging (Albany NY). 2016; 8:231-44. https://doi.org/10.18632/aging.100872 PMID:26851731

81. Wang R, Yu Z, Sunchu B, Shoaf J, Dang I, Zhao S, Caples K, Bradley L, Beaver LM, Ho E, Löhr CV, Perez VI. Rapamycin inhibits the secretory phenotype of senescent cells by a Nrf2-independent mechanism. Aging Cell. 2017; 16:564-74. https://doi.org/10.1111/acel.12587 PMID:28371119

82. Gu Z, Tan W, Ji J, Feng G, Meng Y, Da Z, Guo G, Xia Y, Zhu X, Shi G, Cheng C. Rapamycin reverses the senescent phenotype and improves immunoregulation of mesenchymal stem cells from MRL/lpr mice and systemic lupus erythematosus patients through inhibition of the mTOR signaling pathway. Aging (Albany NY). 2016; 8:1102-14. https://doi.org/10.18632/aging.100925 
PMID: $\underline{27048648}$

83. Kochetkova EY, Blinova GI, Bystrova OA, Martynova MG, Pospelov VA, Pospelova TV. Targeted elimination of senescent ras-transformed cells by suppression of MEK/ERK pathway. Aging (Albany NY). 2017; 9:2352-75.

https://doi.org/10.18632/aging.101325

PMID:29140794

84. Kolesnichenko M, Hong L, Liao R, Vogt PK, Sun P. Attenuation of TORC1 signaling delays replicative and oncogenic RAS-induced senescence. Cell Cycle. 2012; 11:2391-401.

https://doi.org/10.4161/cc.20683

PMID:22627671

85. Demidenko ZN, Korotchkina LG, Gudkov AV, Blagosklonny MV. Paradoxical suppression of cellular senescence by p53. Proc Natl Acad Sci USA. 2010; 107:9660-64.

https://doi.org/10.1073/pnas.1002298107

PMID:20457898

86. Leontieva OV, Demidenko ZN, Blagosklonny MV. Contact inhibition and high cell density deactivate the mammalian target of rapamycin pathway, thus suppressing the senescence program. Proc Natl Acad Sci USA. 2014; 111:8832-37.

https://doi.org/10.1073/pnas.1405723111

PMID:24889617

87. Horvath S, Lu AT, Cohen H, Raj K. Rapamycin retards epigenetic ageing of keratinocytes independently of its effects on replicative senescence, proliferation and differentiation. Aging (Albany NY). 2019; 11:3238-49.

https://doi.org/10.18632/aging.101976

PMID:31136303

88. Cho S, Hwang ES. Status of mTOR activity may phenotypically differentiate senescence and quiescence. Mol Cells. 2012; 33:597-604.

https://doi.org/10.1007/s10059-012-0042-1

PMID:22570149

89. Blagosklonny MV. Does rapamycin slow down time? Oncotarget. 2018; 9:30210-12.

https://doi.org/10.18632/oncotarget.25788

PMID:30100983

90. Kennedy BK, Berger SL, Brunet A, Campisi J, Cuervo AM, Epel ES, Franceschi C, Lithgow GJ, Morimoto RI, Pessin JE, Rando TA, Richardson A, Schadt EE, et al. Geroscience: linking aging to chronic disease. Cell. 2014; 159:709-13.

https://doi.org/10.1016/i.cell.2014.10.039

PMID:25417146

91. Blagosklonny MV. Rejuvenating immunity: "anti-aging drug today" eight years later. Oncotarget. 2015; 6:19405-12. https://doi.org/10.18632/oncotarget.3740

PMID:25844603

92. Chen $C$, Liu $Y$, Liu $Y$, Zheng P. mTOR regulation and therapeutic rejuvenation of aging hematopoietic stem cells. Sci Signal. 2009; 2:ra75.

https://doi.org/10.1126/scisignal.2000559

PMID:19934433

93. Jagannath C, Bakhru P. Rapamycin-induced enhancement of vaccine efficacy in mice. Methods Mol Biol. 2012; 821:295-303.

https://doi.org/10.1007/978-1-61779-430-8 18

PMID:22125073

94. Bravo-San Pedro JM, Senovilla L. Immunostimulatory activity of lifespan-extending agents. Aging (Albany NY). 2013; 5:793-801.

https://doi.org/10.18632/aging.100619

PMID:24389041

95. Araki K, Turner AP, Shaffer VO, Gangappa S, Keller SA, Bachmann MF, Larsen CP, Ahmed R. mTOR regulates memory CD8 t-cell differentiation. Nature. 2009; 460:108-12.

https://doi.org/10.1038/nature08155

PMID:19543266

96. Ferrer IR, Araki K, Ford ML. Paradoxical aspects of rapamycin immunobiology in transplantation. Am J Transplant. 2011; 11:654-59. https://doi.org/10.1111/i.1600-6143.2011.03473.x PMID:21446969

97. Turner AP, Shaffer VO, Araki K, Martens C, Turner PL, Gangappa S, Ford ML, Ahmed R, Kirk AD, Larsen CP. Sirolimus enhances the magnitude and quality of viralspecific CD8+ t-cell responses to vaccinia virus vaccination in rhesus macaques. Am J Transplant. 2011; 11:613-18.

https://doi.org/10.1111/i.1600-6143.2010.03407.x PMID:21342450

98. Hurez V, Dao V, Liu A, Pandeswara S, Gelfond J, Sun L, Bergman M, Orihuela CJ, Galvan V, Padrón Á, Drerup J, Liu $Y$, Hasty $P$, et al. Chronic mTOR inhibition in mice with rapamycin alters $\mathrm{T}, \mathrm{B}$, myeloid, and innate lymphoid cells and gut flora and prolongs life of immune-deficient mice. Aging Cell. 2015; 14:945-56. https://doi.org/10.1111/acel.12380 PMID:26315673

99. Mannick JB, Del Giudice G, Lattanzi M, Valiante NM, Praestgaard J, Huang B, Lonetto MA, Maecker HT, Kovarik J, Carson S, Glass DJ, Klickstein LB. mTOR inhibition improves immune function in the elderly. Sci Transl Med. 2014; 6:268ra179.

https://doi.org/10.1126/scitranslmed.3009892 PMID:25540326

100. Mannick JB, Morris M, Hockey HP, Roma G, Beibel M, Kulmatycki K, Watkins M, Shavlakadze T, Zhou W, 
Quinn D, Glass DJ, Klickstein LB. TORC1 inhibition enhances immune function and reduces infections in the elderly. Sci Transl Med. 2018; 10:eaaq1564.

https://doi.org/10.1126/scitranslmed.aaq1564 PMID:29997249

101. Ferrer IR, Wagener ME, Robertson JM, Turner AP, Araki K, Ahmed R, Kirk AD, Larsen CP, Ford ML. Cutting edge: rapamycin augments pathogen-specific but not graft-reactive $\mathrm{CD} 8+\mathrm{T}$ cell responses. J Immunol. 2010; 185:2004-08.

https://doi.org/10.4049/jimmunol.1001176 PMID:20631309

102. Frasca D, Blomberg BB, Paganelli R. Aging, obesity, and inflammatory age-related diseases. Front Immunol. 2017; 8:1745. https://doi.org/10.3389/fimmu.2017.01745 PMID:29270179

103. Ventura MT, Casciaro M, Gangemi S, Buquicchio R. Immunosenescence in aging: between immune cells depletion and cytokines up-regulation. Clin Mol Allergy. 2017; 15:21.

https://doi.org/10.1186/s12948-017-0077-0 PMID:29259496

104. Gan B, DePinho RA. mTORC1 signaling governs hematopoietic stem cell quiescence. Cell Cycle. 2009; 8:1003-06.

https://doi.org/10.4161/cc.8.7.8045

PMID:19270523

105. Blagosklonny MV. Aging, stem cells, and mammalian target of rapamycin: a prospect of pharmacologic rejuvenation of aging stem cells. Rejuvenation Res. 2008; 11:801-08.

https://doi.org/10.1089/rej.2008.0722

PMID: 18729812

106. Sousa-Victor $P$, Perdiguero $E$, Muñoz-Cánoves $P$. Geroconversion of aged muscle stem cells under regenerative pressure. Cell Cycle. 2014; 13:3183-90. https://doi.org/10.4161/15384101.2014.965072 PMID:25485497

107. Ho YH, Méndez-Ferrer S. Microenvironmental contributions to hematopoietic stem cell aging. Haematologica. 2020; 105:38-46.

https://doi.org/10.3324/haematol.2018.211334 PMID: $\underline{31806690}$

108. Chen J, Kang JG, Keyvanfar K, Young NS, Hwang PM. Long-term adaptation to hypoxia preserves hematopoietic stem cell function. Exp Hematol. 2016; 44:866-73.e4.

https://doi.org/10.1016/j.exphem.2016.04.010 PMID:27118043

109. Takubo K, Goda N, Yamada W, Iriuchishima H, Ikeda E, Kubota Y, Shima H, Johnson RS, Hirao A, Suematsu M,
Suda T. Regulation of the HIF-1alpha level is essential for hematopoietic stem cells. Cell Stem Cell. 2010; 7:391-402.

https://doi.org/10.1016/j.stem.2010.06.020 PMID:20804974

110. Leontieva OV, Natarajan V, Demidenko ZN, Burdelya LG, Gudkov AV, Blagosklonny MV. Hypoxia suppresses conversion from proliferative arrest to cellular senescence. Proc Natl Acad Sci USA. 2012; 109:13314-18.

https://doi.org/10.1073/pnas.1205690109

PMID:22847439

111. Luo Y, Li L, Zou P, Wang J, Shao L, Zhou D, Liu L. Rapamycin enhances long-term hematopoietic reconstitution of ex vivo expanded mouse hematopoietic stem cells by inhibiting senescence. Transplantation. 2014; 97:20-29. https://doi.org/10.1097/TP.0b013e3182a7fcf8 PMID:24092377

112. Feng $X$, Lin $Z$, Sun $W$, Hollinger $M K$, Desierto $M J$, Keyvanfar K, Malide D, Muranski P, Chen J, Young NS. Rapamycin is highly effective in murine models of immune-mediated bone marrow failure. Haematologica. 2017; 102:1691-703. https://doi.org/10.3324/haematol.2017.163675 PMID:28729300

113. Tremblay F, Marette A. Amino acid and insulin signaling via the $\mathrm{mTOR} / \mathrm{p} 70 \mathrm{~S} 6$ kinase pathway. A negative feedback mechanism leading to insulin resistance in skeletal muscle cells. J Biol Chem. 2001; 276:38052-60.

https://doi.org/10.1074/jbc.M106703200 PMID:11498541

114. Manning BD. Balancing Akt with S6K: implications for both metabolic diseases and tumorigenesis. J Cell Biol. 2004; 167:399-403.

https://doi.org/10.1083/jcb.200408161 PMID:15533996

115. Wullschleger $\mathrm{S}$, Loewith $\mathrm{R}$, Hall MN. TOR signaling in growth and metabolism. Cell. 2006; 124:471-84. https://doi.org/10.1016/i.cell.2006.01.016 PMID:16469695

116. Krebs $M$, Brunmair B, Brehm A, Artwohl $M$, Szendroedi J, Nowotny $P$, Roth E, Fürnsinn C, Promintzer M, Anderwald C, Bischof M, Roden M. The mammalian target of rapamycin pathway regulates nutrient-sensitive glucose uptake in man. Diabetes. 2007; 56:1600-07. https://doi.org/10.2337/db06-1016 PMID: 17329620

117. Leontieva OV, Demidenko ZN, Blagosklonny MV. Rapamycin reverses insulin resistance (IR) in highglucose medium without causing IR in normoglycemic 
medium. Cell Death Dis. 2014; 5:e1214. https://doi.org/10.1038/cddis.2014.178 PMID:24810050

118. Khamzina L, Veilleux A, Bergeron S, Marette A. Increased activation of the mammalian target of rapamycin pathway in liver and skeletal muscle of obese rats: possible involvement in obesity-linked insulin resistance. Endocrinology. 2005; 146:1473-81. https://doi.org/10.1210/en.2004-0921 PMID:15604215

119. Blagosklonny MV. Rapamycin for longevity: opinion article. Aging (Albany NY). 2019; 11:8048-67. https://doi.org/10.18632/aging.102355 PMID:31586989

120. Taylor R, Al-Mrabeh A, Zhyzhneuskaya S, Peters C, Barnes AC, Aribisala BS, Hollingsworth KG, Mathers JC, Sattar N, Lean ME. Remission of human type 2 diabetes requires decrease in liver and pancreas fat content but is dependent upon capacity for $\beta$ cell recovery. Cell Metab. 2018; 28:547-56.e3. https://doi.org/10.1016/i.cmet.2018.07.003 PMID:30078554

121. Steven S, Taylor R. Restoring normoglycaemia by use of a very low calorie diet in long- and short-duration type 2 diabetes. Diabet Med. 2015; 32:1149-55. https://doi.org/10.1111/dme.12722 PMID:25683066

122. Steven S, Lim EL, Taylor R. Population response to information on reversibility of type 2 diabetes. Diabet Med. 2013; 30:e135-38. https://doi.org/10.1111/dme.12116 PMID:23320491

123. Nicoll R, Henein MY. Caloric restriction and its effect on blood pressure, heart rate variability and arterial stiffness and dilatation: a review of the evidence. Int J Mol Sci. 2018; 19:751.

https://doi.org/10.3390/ijms19030751 PMID:29518898

124. Blagosklonny MV. Rapamycin and quasi-programmed aging: four years later. Cell Cycle. 2010; 9:1859-62.

https://doi.org/10.4161/cc.9.10.11872

PMID:20436272

125. Johnson SC, Yanos ME, Kayser EB, Quintana A, Sangesland M, Castanza A, Uhde L, Hui J, Wall VZ, Gagnidze A, Oh K, Wasko BM, Ramos FJ, et al. mTOR inhibition alleviates mitochondrial disease in a mouse model of leigh syndrome. Science. 2013; 342:1524-28.

https://doi.org/10.1126/science. 1244360 PMID:24231806

126. Houssaini A, Breau M, Kebe K, Abid S, Marcos E, Lipskaia L, Rideau D, Parpaleix A, Huang J, Amsellem
V, Vienney $N$, Validire $P$, Maitre $B$, et al. mTOR pathway activation drives lung cell senescence and emphysema. JCI Insight. 2018; 3:e93203.

https://doi.org/10.1172/jci.insight.93203 PMID:29415880

127. Mitani A, Ito K, Vuppusetty C, Barnes PJ, Mercado N. Restoration of corticosteroid sensitivity in chronic obstructive pulmonary disease by inhibition of mammalian target of rapamycin. Am J Respir Crit Care Med. 2016; 193:143-53. https://doi.org/10.1164/rccm.201503-05930C PMID:26426522

128. McCormack FX, Inoue Y, Moss J, Singer LG, Strange C, Nakata K, Barker AF, Chapman JT, Brantly ML, Stocks JM, Brown KK, Lynch JP 3rd, Goldberg HJ, et al, National Institutes of Health Rare Lung Diseases Consortium, and MILES Trial Group. Efficacy and safety of sirolimus in lymphangioleiomyomatosis. $\mathrm{N}$ Engl J Med. 2011; 364:1595-606. https://doi.org/10.1056/NEJMoa1100391 PMID:21410393

129. Blagosklonny MV. Fasting and rapamycin: diabetes versus benevolent glucose intolerance. Cell Death Dis. 2019; 10:607.

https://doi.org/10.1038/s41419-019-1822-8 PMID:31406105

130. Pavlakis M, Goldfarb-Rumyantzev AS. Diabetes after transplantation and sirolimus: what's the connection? J Am Soc Nephrol. 2008; 19:1255-56. https://doi.org/10.1681/ASN.2008050474 PMID:18579636

131. Veroux M, Tallarita $T$, Corona $D$, Sinagra N, Giaquinta A, Zerbo D, Guerrieri C, D’Assoro A, Cimino S, Veroux P. Conversion to sirolimus therapy in kidney transplant recipients with new onset diabetes mellitus after transplantation. Clin Dev Immunol. 2013; 2013:496974.

https://doi.org/10.1155/2013/496974

PMID:23762090

132. Tanimura J, Nakagawa $H$, Tanaka $T$, Kikuchi A, Osada S, Tanaka Y, Tokuyama K, Takamura T. The clinical course and potential underlying mechanisms of everolimus-induced hyperglycemia. Endocr J. 2019; 66:615-20.

https://doi.org/10.1507/endocri.EJ18-0542 PMID:30982794

133. Zhou Y, Hou Y, Shen J, Huang Y, Martin W, Cheng F. Network-based drug repurposing for novel coronavirus 2019-nCoV/SARS-CoV-2. Cell Discov. 2020; 6:14.

https://doi.org/10.1038/s41421-020-0153-3 PMID:32194980 
134. Omarjee L, Janin A, Perrot F, Laviolle B, Meilhac O, Mahe G. Targeting t-cell senescence and cytokine storm with rapamycin to prevent severe progression in COVID-19. Clin Immunol. 2020; 216:108464. https://doi.org/10.1016/j.clim.2020.108464 PMID:32405269

135. Zheng Y, Li R, Liu S. Immunoregulation with mTOR inhibitors to prevent COVID-19 severity: a novel intervention strategy beyond vaccines and specific antiviral medicines. J Med Virol. 2020; 10:1002.

https://doi.org/10.1002/jmv.26009

PMID:32410266

136. Maiese K. The mechanistic target of rapamycin (mTOR): novel considerations as an antiviral treatment. Curr Neurovasc Res. 2020. [Epub ahead of print].

https://doi.org/10.2174/1567202617666200425205 122 PMID: $\underline{32334502}$

137. Lehrer S. Inhaled biguanides and mTOR inhibition for influenza and coronavirus (review). World Acad Sci J. 2020; 2:1. https://doi.org/10.3892/wasj.2020.42 PMID:32313883

138. Zou J, Zou P, Wang J, Li L, Wang Y, Zhou D, Liu L. Inhibition of p38 MAPK activity promotes ex vivo expansion of human cord blood hematopoietic stem cells. Ann Hematol. 2012; 91:813-23.

https://doi.org/10.1007/s00277-011-1397-7 PMID:22258328

139. Ranadheera C, Coombs KM, Kobasa D. Comprehending a killer: the Akt/mTOR signaling pathways are temporally high-jacked by the highly pathogenic 1918 influenza virus. EBioMedicine. 2018; 32:142-63.

https://doi.org/10.1016/i.ebiom.2018.05.027 PMID:29866590

140. Kindrachuk J, Ork B, Hart BJ, Mazur S, Holbrook MR, Frieman MB, Traynor D, Johnson RF, Dyall J, Kuhn JH, Olinger GG, Hensley LE, Jahrling PB. Antiviral potential of ERK/MAPK and PI3K/AKT/mTOR signaling modulation for middle east respiratory syndrome coronavirus infection as identified by temporal kinome analysis. Antimicrob Agents Chemother. 2015; 59:1088-99.

https://doi.org/10.1128/AAC.03659-14

PMID:25487801

141. Seminari E, Colaneri M, Sambo M, Gallazzi I, Di Matteo A, Roda S, Bruno R, and COVID19 IRCCS San Matteo Pavia Task Force. SARS cov-2 infection in a renal-transplanted patient: a case report. Am J Transplant. 2020. [Epub ahead of print]. https://doi.org/10.1111/ajt.15902 PMID:32243672

142. Mehta P, McAuley DF, Brown M, Sanchez E, Tattersall RS, Manson JJ, and HLH Across Speciality Collaboration, UK. COVID-19: consider cytokine storm syndromes and immunosuppression. Lancet. 2020; 395:1033-34.

https://doi.org/10.1016/S0140-6736(20)30628-0 PMID: $\underline{32192578}$

143. Coperchini F, Chiovato L, Croce L, Magri F, Rotondi M. The cytokine storm in COVID-19: an overview of the involvement of the chemokine/chemokine-receptor system. Cytokine Growth Factor Rev. 2020; 53:25-32. https://doi.org/10.1016/i.cytogfr.2020.05.003 PMID:32446778

144. Rolt A, Nair A, Cox LS. Optimisation of a screening platform for determining IL-6 inflammatory signalling in the senescence-associated secretory phenotype (SASP). Biogerontology. 2019; 20:359-71. https://doi.org/10.1007/s10522-019-09796-4 PMID:30741380

145. Chiang PH, Wang L, Bonham CA, Liang X, Fung JJ, Lu L, Qian S. Mechanistic insights into impaired dendritic cell function by rapamycin: inhibition of Jak2/Stat4 signaling pathway. J Immunol. 2004; 172:1355-63. https://doi.org/10.4049/jimmunol.172.3.1355 PMID:14734710

146. Wang $\mathrm{CH}$, Chung FT, Lin SM, Huang SY, Chou CL, Lee KY, Lin TY, Kuo HP. Adjuvant treatment with a mammalian target of rapamycin inhibitor, sirolimus, and steroids improves outcomes in patients with severe H1N1 pneumonia and acute respiratory failure. Crit Care Med. 2014; 42:313-21. https://doi.org/10.1097/CCM.0b013e3182a2727d PMID:24105455 


\section{SUPPLEMENTARY MATERIALS}

\section{Supplementary Figure}

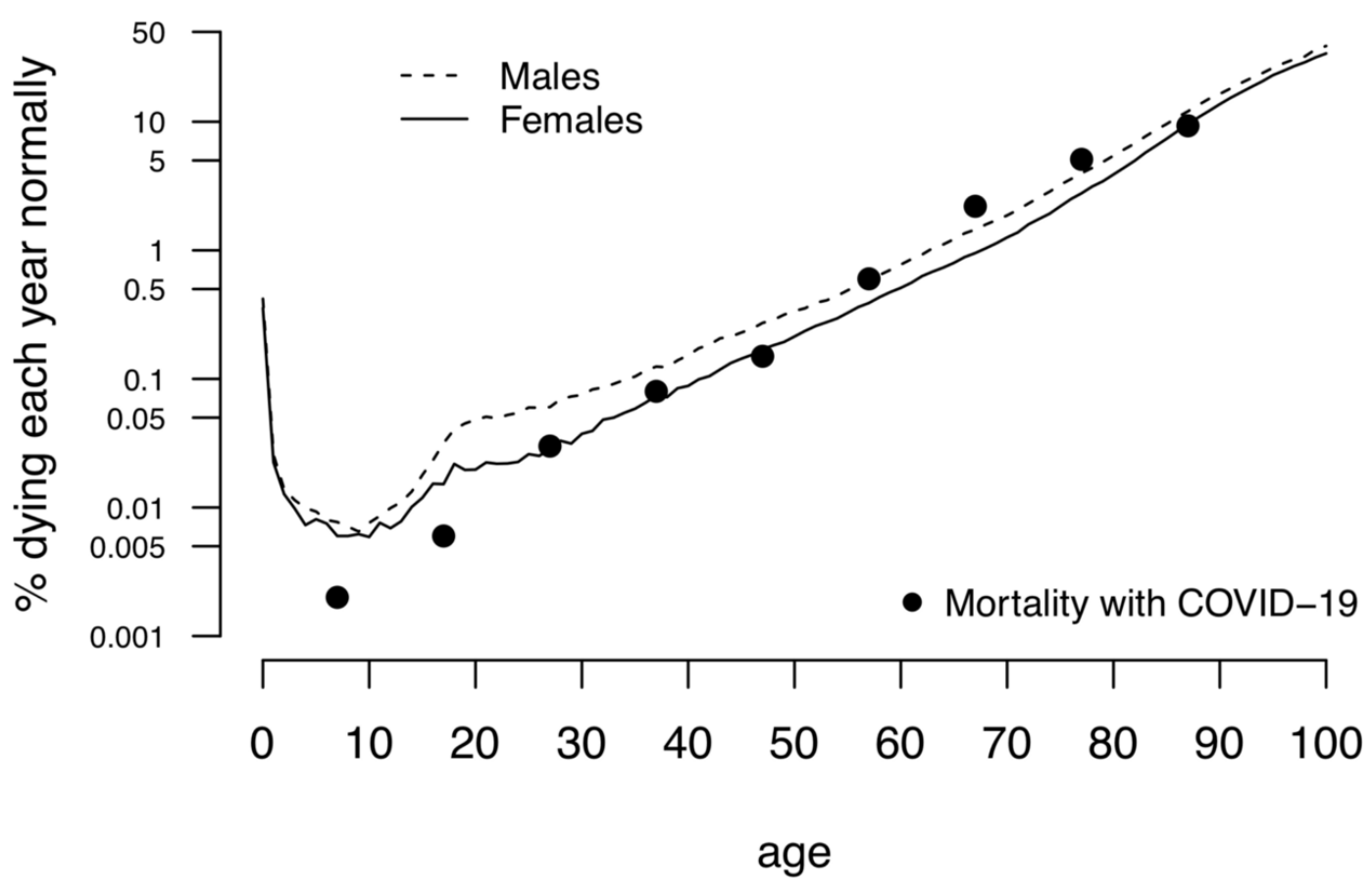

Supplementary Figure 1. The mortality risk with COVID-19 superimposed on background annual risk. Annual risk of death (hazard) for England and Wales, 2016-2018, from Office for National Statistics. https://medium.com/wintoncentre/how-much-normal-riskdoes-covid-represent-4539118e1196. 